\title{
Pulmonary thromboembolism in an emergency hospital: Are our patients different?
}

\author{
ANA MARIA BALAHURA ${ }^{1,2}$, ANDRADA GUȚ $\breve{A}^{3}$, VLAD MIHALCEA $^{1}$, EMMA WEISS $^{1,2}$, MARIA DOROBANȚU $^{1,2}$, \\ DANIELA BARTOȘ ${ }^{1,2}$, ELISABETA BĂDILA ${ }^{1,2}$ GHEORGHE ANDREI DAN ${ }^{1,4}$ \\ 1“"Carol Davila" University of Medicine and Pharmacy, Bucharest, Romania \\ 2"Floreasca" Clinical Emergency Hospital Bucharest, Romania \\ 3“C.C. Iliescu” Emergency Institute for Cardiovascular Diseases, Bucharest, Romania \\ 4"Colentina" Clinical Hospital, Bucharest, Romania
}

\begin{abstract}
Introduction. Pulmonary thromboembolism (PTE) represents a medical emergency and is the third most common cause of mortality after myocardial infarction and stroke. The purpose of this study was to describe the characteristics and management of patients with PTE admitted in a referral emergency hospital in Romania.

Material and methods. We retrospectively reviewed all cases of PTE diagnosed in one of the largest emergency hospitals in Bucharest during a 2-year period (January 2014 - December 2016). Patients with acute PTE were identified by a database search of the diagnostic codes of all discharge diagnoses. Demographic, clinical and paraclinical tests data was retrieved from medical records.

Results. 221 patients $(48.87 \%$ male, mean age 61.76 years (range 21-94 years)) were diagnosed with PTE in our hospital (0.31\% of all hospitalizations). Dyspnea was the most frequent symptom reported (78.9\%), followed by pleuritic chest pain $(23.9 \%)$ and unilateral leg pain $(15.8 \%)$. Upon presentation, $12.6 \%$ of patients had high-risk PTE. Up to $72.8 \%$ of patients had at least one thrombotic risk factor, while cancer (14\%) was the most frequent amongst them. The mean length of hospitalization was $10.3 \pm 4.6$ days. Unfractioned heparin (UFH) was the preferred anticoagulant during hospital stay $(73.7 \%, \mathrm{p}<0.001)$. Vitamin $\mathrm{K}$ antagonists $(\mathrm{AVK})$ were the preferred anticoagulant $(71.7 \%, \mathrm{p}<0.001)$ after discharge, whereas non-antivitamin $\mathrm{K}$ oral anticoagulants (NOAC) were recommended in $26.3 \%$ of patients. Thrombolysis was used in $18(8.4 \%)$ cases. Mortality was $0.9 \%$.

Younger patients more frequently associated thrombophilia or a previous thromboembolic event and clinical signs of DVT at presentation. Older patients associated more frequently a history of hospitalization for heart failure or atrial fibrillation during the previous 3 months and a history of cancer. The clinical presentation in older patients was more severe, with higher PESI scores $(103.6 \pm 33.4$ $v s .55 .5 \pm 17.9, \mathrm{p}<0.001)$ and a longer hospital stay $(10.7 \pm 4.7 v s .9 .2 \pm 3.9, \mathrm{p}=0.03)$. The type of anticoagulant treatment did not differ depending on age.

Conclusion. In our emergency hospital, PTE is a relatively rare cause of hospitalization; the rate is, however, comparable with other major hospitals. Dyspnea and pleuritic chest pain was the clinical presentation dyad. UFH was the preferred anticoagulant for in-hospital treatment while AVK was the preferred option for long term treatment and recurrence prophylaxis; however an increasing number of patients are prescribed NOAC. In older patients clinical severity was higher upon presentation, hospitalization duration was increased and cancer was more frequently associated. Younger patients associated more frequently a primary hypercoagulable state and recurrent thromboembolism. Mortality rate was low during hospitalization, comparable with that seen in other studied populations.
\end{abstract} coagulation.

Key words: pulmonary embolism, hospitalization, risk factors, computed tomography, anti-

\section{INTRODUCTION}

Pulmonary thromboembolism (PTE) represents a medical emergency and is the third most common cause of mortality after myocardial infarction and stroke [1]. The incidence of PTE among the European population exceeds 1 per 1000 [2]. There are several international registries created in order to evaluate the incidence, demographic and clinical characteristics, as well as prognosis of patients diagnosed with PTE [3, 4]. In 2009, The Romanian Registry of Pulmonary Thromboembolism (RO-TEP) has been created with a priority in evaluating epidemiologic, therapeutic and clinical outcome differences in patients admitted for PTE in several hospitals in Romania. Data reported so far is scarce and the RO-TEP Registry can thus far offer an accurate view on PTE patients characteristics and management [5]. Nonetheless, 
the results of this registry are still unpublished and data on characteristics of management in emergency hospitals is not currently available.

The purpose of this study was to describe the characteristics and management of patients with PTE admitted in a referral emergency hospital in Romania.

\section{MATERIAL AND METHODS}

We retrospectively reviewed all cases of PTE diagnosed in a county emergency hospital during a 2-year period from January 2014 through December 2016. Patients with acute PTE were identified by a data search of the diagnostic codes of all discharge diagnoses (primary and secondary diagnoses). The medical records of all of the patients with a diagnosis of PTE were reviewed for objective evidence of PE. Demographic, clinical and paraclinical tests data was retrieved from the medical records.

Probability and severity scores were calculated retrospectively, according to the European guideline for diagnosis and management of pulmonary embolism (ESC guideline) [6].

In order to characterize PTE clinical patterns according to age, in the analysis, patients were further divided into two groups, Group 1 with 54 (24.4\%) patients under 50 years of age and Group 2 with $167(75.6 \%)$ patients aged 50 years or older.

Ethical approval for the study was granted by the Hospital Committee for Research Ethics.

\section{Statistical analysis}

The categorical variables were presented as counts and percentages, while continuous variables were presented as mean values \pm standard deviation. The frequency of clinical and paraclinical characteristics in the groups was compared using two-bytwo contingency table and analyzed with chi-square $\chi 2$ with Yates correction test. Continuous variables were compared using Student T test. A p-value < 0.05 was considered statistically significant. Statistical analysis was performed with the Statistical Package for the Social Sciences (SPSS) 23.0 for Windows.

\section{RESULTS}

During the 2 year study period, 221 patients (48.87\% male, male: female ratio $1: 1.04)$ were diagnosed with PTE in our hospital, summing up to $0.31 \%$ of all hospitalizations. Mean age at diagnosis was 61.76 years (range $21-94$ years). Two $(0.9 \%)$ patients died during hospitalization.

Diagnosis of PTE was proven following a combination of clinical evaluation and laboratory and imaging tests. Clinical evaluation, estimation of Wells score and revised Geneva score were done in all patients. D-dimer levels were measured in $37.1 \%$ of patients, lower limb ultrasound for deep venous thrombosis (DVT) was done in $51.1 \%$ patients, 2D and Doppler echocardiography in 37.5\% patients and chest computer tomography in $90.04 \%$ of patients.

\section{Clinical presentation}

Clinical picture in patients diagnosed with PTE in the emergency department is displayed in Table 1. Dyspnoea was the most frequent symptom reported followed by pleuritic chest pain and unilateral leg pain, whereas hemoptysis and fever were found in only a minority of patients. Clinical signs of DVT were present in $72(32.6 \%)$ cases and 40 (18.1\%) patients had a history of PTE. Tachycardia, defined as a heart rate over $100 \mathrm{bpm}$, was found in $87(39.3 \%)$ patients.

Up to $72.8 \%$ of patients had at least one thrombotic risk factor. Patient comorbidities and risk predictors are detailed in Table 2.

Table 1

Frequency of symptoms reported by patients diagnosed with PTE in the emergency department

\begin{tabular}{|l|c|c|c|c|}
\hline \multicolumn{1}{|c|}{ Variables } & $\begin{array}{c}\text { Total } \\
\text { No }(\mathbf{\%})\end{array}$ & $\begin{array}{c}\text { Group 1 } \\
(<\mathbf{5 0} \text { years), no (\%) }\end{array}$ & $\begin{array}{c}\text { Group 2 } \\
(\geq \mathbf{5 0 y e a r s ) , ~ n o ~ ( \% ) ~}\end{array}$ & p-value \\
\hline Number (\%) & 221 & $54(24.4)$ & $167(75.6)$ & - \\
\hline Male sex & $108(48.8)$ & $29(53.7)$ & $79(47.3)$ & 0.4 \\
\hline Symptoms & $174(87.7)$ & $36(66.6 \%)$ & $142(85.0)$ & 0.003 \\
\hline Dyspnea & $52(23.5)$ & $18(33.3)$ & $34(20.3)$ & 0.05 \\
\hline Pleuritic chest pain & $34(15.3)$ & $12(22.2)$ & $22(13.1)$ & 0.10 \\
\hline Unilateral leg pain & $34(15.3)$ & $6(11.1)$ & $28(16.7)$ & 0.05 \\
\hline Substernal chest pain & $33(14.9)$ & $7(12.9)$ & $26(15.5)$ & 0.6 \\
\hline Syncope & $27(12.2)$ & $11(20.3)$ & $16(9.5)$ & 0.03 \\
\hline Cough & $14(6.3)$ & $7(12.9)$ & $7(4.1)$ & 0.02 \\
\hline Hemoptysis & $4(1.8)$ & $2(3.7)$ & $2(1.1)$ & 0.22 \\
\hline Fever & $72(32.5)$ & $23(42.5)$ & $49(29.3)$ & 0.07 \\
\hline Signs of DVT
\end{tabular}

DVT - deep vein thrombosis. 
Table 2

Patient comorbidities and risk predictors for PTE

\begin{tabular}{|c|c|c|c|c|}
\hline Variables & $\begin{array}{c}\text { Total } \\
\text { No }(\%) \\
\end{array}$ & $\begin{array}{c}\text { Group } 1 \\
(<50 \text { years }), \text { no }(\%) \\
\end{array}$ & $\begin{array}{c}\text { Group } 2 \\
(\geq 50 \text { years), no }(\%)\end{array}$ & p-value \\
\hline Number (\%) & 221 & $54(24.4)$ & $167(75.6)$ & - \\
\hline Male sex & $108(48.8)$ & $29(53.7)$ & $79(47.3)$ & 0.4 \\
\hline \multicolumn{5}{|l|}{ Risk factors } \\
\hline At least 1 risk factor & $106(47.9)$ & $24(44.4)$ & $82(49.1)$ & 0.5 \\
\hline Cancer & $31(14.0)$ & $0(0)$ & $31(18.5)$ & 0.02 \\
\hline Major trauma & $27(12.2)$ & $5(9.2)$ & $22(13.1)$ & 0.4 \\
\hline $\begin{array}{l}\text { History of hospitalization for } \mathrm{HF} \text { or } \mathrm{AF} \\
\text { in the previous } 3 \text { months }\end{array}$ & $23(10.4)$ & $0(0)$ & $23(13.7)$ & 0.004 \\
\hline Chemotherapy & $13(5.8)$ & $0(0)$ & $13(7.7)$ & 0.034 \\
\hline Lower limb fracture & $12(5.4)$ & $5(9.2)$ & $7(4.1)$ & 0.1 \\
\hline Severe infections & $11(4.9)$ & $3(5.5)$ & $8(4.7)$ & 0.8 \\
\hline Use of contraceptives & $7(3.1)$ & $7(12.9)$ & $0(0)$ & $<0.001$ \\
\hline Therapy with hormones & $7(3.1)$ & $2(3.7)$ & $5(2.9)$ & 0.79 \\
\hline Knee or hip replacement & $5(2.2)$ & $1(1.8)$ & $4(2.3)$ & 0.8 \\
\hline Thrombophilia & $5(2.2)$ & $5(9.2)$ & $0(0)$ & $<0.001$ \\
\hline Respiratory insufficiency & $5(2.2)$ & $0(0)$ & $5(2.9)$ & 0.19 \\
\hline Autoimmune disease & $2(0.9)$ & $0(0)$ & $2(1.1)$ & 0.41 \\
\hline Previous VTE & $40(18.0)$ & $16(29.6)$ & $24(14.3)$ & 0.01 \\
\hline
\end{tabular}

$\mathrm{AF}$ - atrial fibrillation, NOAC - direct oral anticoagulant, DVT - deep vein thrombosis, HF- heart failure, LV - left ventricle, PTE - pulmonary thromboembolism, RV - right ventricle, VTE - venous thromboembolism.

\section{Probability of PTE and risk stratification}

Pre-test probability was assessed using both Wells and revised Geneva scores, the simplified versions. Wells score misclassified as PE unlikely $22.1 \%$ of patients, whereas the revised Geneva score misclassified significantly more, $40.2 \%$ of patients that were subsequently diagnosed with PE (Table 3).
Based on patient clinical status upon presentation, $12.6 \%$ of patients were classified as high risk PTE (with shock/hypotension) and the remainder as non-high risk. According to the original version of the PESI (Pulmonary embolism severity index) score, a quarter of patients were at high or very high mortality risk, while another quarter was at low risk (Table 4).

Table 3

Probability of PTE in the study groups

\begin{tabular}{|c|c|c|c|c|c|c|}
\hline & \multicolumn{2}{|c|}{ Wells Score } & \multicolumn{2}{|c|}{ rGeneva Score } & Total & P-value ${ }^{\&}$ \\
\hline & PE likely & PE unlikely & PE likely & PE unlikely & & \\
\hline $\begin{array}{l}\text { Group 1 } \\
(<50 \text { y) }\end{array}$ & $47(87.0 \%)$ & $7(13.0 \%)$ & $26(48.1 \%)$ & $28(51.8 \%)$ & 54 & 0.005 \\
\hline $\begin{array}{l}\text { Group 2 } \\
\text { ( } \geq 50 y) \\
\text { P-value* }\end{array}$ & $\begin{array}{c}125(74.8 \%) \\
0.09\end{array}$ & $42(25.2 \%)$ & $\begin{array}{c}106(63.4 \%) \\
0.04\end{array}$ & $61(36.6 \%)$ & 167 & 0.02 \\
\hline Total & $172(77.8 \%)$ & $49(22.2 \%)$ & $132(59.7 \%)$ & $89(40.3 \%)$ & 221 & $<0.001$ \\
\hline
\end{tabular}

rGeneva score - revised Geneva score, PTE - pulmonary embolism; *PE likely in patients $\leq 50$ versus $>50$ years. ${ }^{*}$ PE likely with the Wells versus the rGeneva Score.

Table 4

PESI (Pulmonary embolism severity index) score in the study groups

\begin{tabular}{|c|c|c|c|c|}
\hline PESI class risk & Group 1 (<50 y) & Group 2 ( $\mathbf{5 0 y})$ & Total & P-value* \\
\hline I & $41(75.9 \%)$ & $15(8.9 \%)$ & $56(25.3 \%)$ & $<0.001$ \\
II & $8(14.8 \%)$ & $38(22.7 \%)$ & $46(20.8 \%)$ & 0.20 \\
III & $5(9.2)$ & $55(32.9 \%)$ & $60(27.1 \%)$ & $<0.001$ \\
IV & $0(0 \%)$ & $27(16.1 \%)$ & $27(12.2 \%)$ & - \\
V & $0(0 \%)$ & $32(19.1 \%)$ & $32(14.4 \%)$ & - \\
\hline 54 & 167 & 221 & \\
\hline
\end{tabular}

$*$ Age $<50$ versus age $\geq 50$ years.

\section{Treatment}

The mean length of hospitalization was $10.3 \pm$ 4.6 days. No difference in length of hospital stay was found comparing patients initiated on non- antivitamin $\mathrm{K}$ oral anticoagulants (NOAC) versus those receiving parenteral anticoagulation (10.8 \pm 4.4 vs. $10.6 \pm 4.2$ days, p-value 0.8 ) during hospitalization. With respect to treatment, in $96.8 \%$ of 
patients anticoagulation with either unfractioned heparin (UFH), low molecular weight heparin (LMWH) or NOAC was initiated in the hospital. Three patients had major trauma that impeded anticoagulant administration while for the remainder, no contraindication was found. UFH was the preferred anticoagulant during hospital stay $(73.7 \%$, $\mathrm{p}<0.001$ ). Upon discharge, anticoagulation was recommended in 205 (92.7\%) patients. Vitamin K antagonists (AVK) were the preferred anticoagulant $(71.7 \%, \mathrm{p}<0.001)$ whereas NOAC were recommended in $26.3 \%$ of patients.

Thrombolysis was used in $18(8.4 \%)$ cases, in 17 cases as systemic thrombolysis and in 1 patient as catheter directed local thrombolysis (Table 5). From these patients, $7(38.8 \%)$ received primary reperfusion.

Table 5

Treatment in the study groups

\begin{tabular}{|c|c|c|c|c|c|c|c|c|c|c|c|}
\hline & \multicolumn{3}{|c|}{$\begin{array}{c}\text { During hospitalization } \\
(\text { No }(\%))\end{array}$} & \multirow[t]{2}{*}{ Total } & \multicolumn{3}{|c|}{$\begin{array}{c}\text { Anticoagulation after discharge } \\
(\text { No (\%)) }\end{array}$} & \multirow[t]{2}{*}{ Total } & \multicolumn{2}{|c|}{$\begin{array}{c}\text { Thrombolysis } \\
\text { (No (\%)) }\end{array}$} & \multirow[t]{2}{*}{ Total } \\
\hline & UFH & LMWH & NOAC & & LMWH & NOAC & AVK & & No & Yes & \\
\hline $\begin{array}{l}\text { Group } 1 \\
(<50 \text { y) }\end{array}$ & $\begin{array}{c}40 \\
(74.0)\end{array}$ & $\begin{array}{c}5 \\
(9.2)\end{array}$ & $\begin{array}{c}9 \\
(16.6)\end{array}$ & 54 & $\begin{array}{c}2 \\
(4.0)\end{array}$ & $\begin{array}{c}14 \\
(28.5)\end{array}$ & $\begin{array}{c}33 \\
(67.3)\end{array}$ & 49 & $\begin{array}{c}51 \\
(94.4)\end{array}$ & $\begin{array}{c}3 \\
(5.6)\end{array}$ & 54 \\
\hline $\begin{array}{l}\text { Group } 2 \\
(\geq 50 \mathrm{y})\end{array}$ & $\begin{array}{c}123 \\
(76.8) \\
\end{array}$ & $\begin{array}{c}9 \\
(5.6) \\
\end{array}$ & $\begin{array}{c}28 \\
(17.5)\end{array}$ & 160 & $\begin{array}{c}2 \\
(1.2)\end{array}$ & $\begin{array}{c}40 \\
(25.6)\end{array}$ & $\begin{array}{c}114 \\
(73.0)\end{array}$ & 156 & $\begin{array}{c}152 \\
(91.0)\end{array}$ & $\begin{array}{c}15 \\
(9.0)\end{array}$ & 167 \\
\hline Total & 163 & 14 & 37 & 214 & 4 & 54 & 147 & 205 & 203 & 18 & 221 \\
\hline P-value & 0.6 & 0.3 & 0.8 & & 0.2 & 0.6 & 0.4 & & & 0.4 & \\
\hline
\end{tabular}

AVK - vitamin K antagonists, NOAC - direct oral anticoagulant, LMWH - low molecular weight heparine, UFH - unfractioned heparine.

\section{PTE in young patients}

Young patients, under 50 years of age, represented almost a quarter of the PTE patients. Their clinical and biological profile as compared to that of older patients with PTE is represented in Tables 1-2. Patients clinical probability for PTE in the two groups, based on Wells and Geneva revised scores, is illustrated in Table 3 and the PESI score in Table 4.

Older patients had more frequently a history of hospitalization for HF or atrial fibrillation (AF) during the previous 3 months, and a history of cancer, while younger patients had more frequently a form of thrombophilia or a previous thromboembolic event (Table 2). Older patients presented more frequently with chest pain and dyspnea, while younger patients presented with clinical signs of DVT (Table 1). The clinical presentation in older patients was more severe with higher PESI score and a longer hospital stay (Table 6). The type of anticoagulant treatment did not differ between groups (Table 5). The Wells score indicated 'PTE likely' more frequently than the revised Geneva score in the patients diagnosed with PTE (Table 3).

Table 6

Imaging and severity characteristics in young patients versus older PTE patients

\begin{tabular}{|c|c|c|c|c|}
\hline Variables & Total & $\begin{array}{c}\text { Group } 1 \\
(<50 \text { years })\end{array}$ & $\begin{array}{c}\text { Group } 2 \\
(\geq 50 \text { years })\end{array}$ & p-value \\
\hline Number (\%) & 221 & $54(24.4)$ & $167(75.6)$ & - \\
\hline Male sex & $108(48.8)$ & $29(53.7)$ & $79(47.3)$ & 0.4 \\
\hline \multicolumn{5}{|l|}{ AngioCT scan (no (\%)) } \\
\hline *Central PTE & $148(66.9)$ & $35(64.8)$ & $113(67.6 \%$ & 0.6 \\
\hline \multicolumn{5}{|l|}{ Echocardiography (no (\%)) } \\
\hline Dilated RV & $58(26.2)$ & $9(16.6)$ & $49(29.3)$ & 0.06 \\
\hline RV dysfunction & $38(17.1)$ & $6(11.1)$ & $32(19.1)$ & 0.17 \\
\hline LV dysfunction & $26(11.7)$ & $3(5.5)$ & $23(13.7)$ & 0.10 \\
\hline \multicolumn{5}{|l|}{ Other severity parameters } \\
\hline PESI score & $91.6 \pm 36.7$ & $55.5 \pm 17.9$ & $103.6 \pm 33.4$ & $<0.001$ \\
\hline Hospitalization days & $10.3 \pm 4.6$ & $9.2 \pm 3.9$ & $10.7 \pm 4.7$ & 0.03 \\
\hline
\end{tabular}

LV - left ventricle, PTE - pulmonary thromboembolism, RV - right ventricle, VTE - venous thromboembolism. ${ }^{*}$ Central PTE indicates the involvement of the right or left pulmonary artery.

\section{DISCUSSION}

In the present study we analyzed the clinical and paraclinical profile of patients admitted for PTE in a major emergency hospital from Romania.
PTE diagnosis represented $0.31 \%$ of all hospitalizations during the 2-year studied period, an incidence rate similar to those reported in the United States (between 0.047-0.40\%) [7]. Our data is limited to PE patients who were hospitalized, 
and PTE diagnosis could be more frequent in the emergency department, even though admittance rates reported in the US are around $86 \%$ [8].

The two most frequent symptoms were dyspnea and pleuritic chest pain, whereas clinical signs of DVT appeared in a third of patients only, thus emphasizing once more that clinical suspicion of PTE should be based on a combination of signs and symptoms as the Wells and revised Geneva scores taken into consideration [6]. In the present study, which evaluated patients diagnosed with PTE, the revised Geneva score indicated significantly more frequently a low probability for PTE than the Wells rule. The retrospective calculation of these scores may explain the difference between the two scores; however, there are several other studies that emphasize the same discrepancy [9].

In less than a quarter of patients we found no thrombotic risk factors, a result in accordance with other studies reporting percentages of $15-40 \%$ of unprovoked PE [10]. Even though in younger patients risk factors are frequently absent, in our study there was no difference between young and older patients regarding the number of unprovoked PTE [11]. The emergency profile of the hospital in which the study was undertaken might have led to a selected population of young patients with a more severe clinical status or comorbidities. For instance, there were no differences in the percentage of young and older patients with limb fractures or major trauma. Nonetheless, the profile of thrombotic risk factors differs between groups, with thrombophilia being more frequent in the young, while cancer and prior hospitalizations for HF or AF are more frequent in the older patients as it would be expected considering the age-dependent prevalence of the respective diseases in the general population $[12,13]$.

Diagnosis of PTE in our hospital is based on internal protocols in accordance with the ESC guidelines. Therefore, after clinical evaluation and PTE probability assessment, in most cases, CT angiography was the next diagnostic step as it is readily available, preceded or not by D-Dimer testing as dictated by the clinical probability scores [6]. Two thirds of patients were diagnosed with central PTE at CT angiography, defined as thrombi in the lobar arteries. Interestingly, there was no difference in the prevalence of central PE between the two studied groups, even though the severity of clinical presentation in the older patients was significantly higher as assessed by the PESI score. However, we found similar proportions of RV dysfunction and dilation assessed by echocardiography in the young versus older patients. This could be the result of the overall greater cardiovascular fitness and reserve of young patients along with the increased number of comorbidities in the older patients, especially HF. The in-hospital mortality was very low $(0.9 \%)$, smaller than the overall mortality reported by older studies of $11-15 \%$ [14, 15]. The more recent EMPEROR registry, including however younger patients, reported an in-hospital mortality related to PTE of $1.1 \%$ similar to our data [16]. The lower mortality in our study could be partially explained by its retrospective nature and the possible different coding in the electronic system of deaths that occurred in the emergency department without hospital admission. Nonetheless, we found a long hospital stay and more so in the case of older patients reflecting probably the case severity, even though completion of the 5-10 days of the parenteral anticoagulant therapy could have been a deciding factor [6]. However, we found no difference in hospital stay length between patients receiving non-AVK oral anticoagulants versus those receiving parenteral anticoagulant, as opposed to recent studies showing that PTE in patients treated with NOAC had shorter hospital stays [17, 18].

In-hospital treatment consisted in anticoagulation in almost all patients, with UFH being the preferred anticoagulant (73.7\%). Cost and availability could have been an important factor when deciding for $\mathrm{UFH}$, as the ESC guideline recommends UFH especially for high risk PTE, a situation where LMWH were not studied, whereas in intermediate or low-risk PTE LMWH are the first choice. Nonetheless, in the EMPEROR registry including a large U.S. sample, UFH was initiated in $53.6 \%$ of patients even though only $3 \%$ presented with PTE with shock/hypotension [16]. Only $17.2 \%$ received NOAC even though rivaroxaban and apixaban can be safely administered in patients with PTE without shock or hypotension according to the EINSTEIN$P E$ and AMPLIFY trials and the current ESC guideline $[19,20]$. Even apixaban and rivaroxaban were only recently approved and became available in hospitals in Romania. They were however recommended as out-of-hospital anticoagulation in $26.3 \%$ of our patients. Nonetheless, the still prohibitive cost of this NOAC could hamper their recommenddation in the following period.

The oral anticoagulant preferred for the outof-hospital anticoagulation was the AVK acenocumarol, an old drug and less costly option for PTE patients from Romania [21]. LMWH at discharge 
was prescribed to 4 patients with active cancer as recommended by the current guideline.

Apart from anticoagulant treatment, thrombolysis was used in $8.1 \%$ of patients of which only a third was used as primary reperfusion therapy, even though $12.6 \%$ presented with high risk PTE. The retrospective nature of this study did not allow evaluation for contraindication to reperfusion therapy, even though, according to the current guideline, most contraindications should be considered relative in patients with life-threatening, high-risk PTE [6].

\section{Study limitations}

Our study is a single-center report and its retrospective nature limits the data available for analysis. We could not retrieve data on the timeline and diagnostic steps followed in every patient, therefore, we could only assume the appropriateness of diagnostic tools that were used when following the ESC guideline recommendations. For instance, almost half of patients underwent venous Doppler ultrasound even though its role in PTE diagnostic workup is mainly as an alternative in patients with contraindication to CT angiography [6].

Moreover, we obtained data from patients admitted starting from January 2014 when NOAC were only becoming available in Romanian hospitals, therefore, the proportion of patients receiving NOAC might be higher now than reported in the current study.

\section{CONCLUSION}

In our emergency hospital, PTE is a relatively rare cause of hospitalization; the rate is however comparable with other major hospitals. Dyspnea and pleuritic chest pain was the clinical presentation dyad, while CT angiography was the imaging diagnostic tool in the majority of patients. UFH was the preferred anticoagulant for in-hospital treatment while AVK was the preferred option for long term treatment and recurrence prophylaxis; however, an increasing number of patients are prescribed NOAC. Older patients have higher severity at presentations, longer hospitalization and an increased cancer frequency, younger patients present more with primary hypercoagulable state and recurrent thromboembolism. Mortality rate was low during hospitalization, comparable with that seen in other studied populations.

Founding source: This work was possible due to the MODERNIZE project (Modernization of infrastructure in the center of research - development in minimally invasive interventional medical techniques in internal medicine and gastroenterology), funded by the National Authority of Scientific Research and Innovation, in the name of the Ministry of European Funds, through the Operational Program Increase of Economic Competitiveness, Priority axis $2=$ Operation 2.2.1 (POSCCE-A2-0.2.2.1- 2013-1), co-financed by the European Regional Development Fund.

Conflict of interest: The authors have no conflict of interest.

Introducere. Tromboembolismul pulmonar reprezintă o urgență medicală şi este a treia cauză ca frecvență de mortalitate după infarctul miocardic şi accidentul vascular cerebral. Scopul acestui studiu a fost de a descrie caracteristicile şi managementul pacienților cu PTE internați într-un spital de urgență de referință din România.

Material şi metodă. Am analizat retrospectiv toate cazurile de PTE diagnosticate intr-unul din cele mai mari spitale de urgență din Bucureşti pe o perioadă de 2 ani (Ianuarie 2014 - Decembrie 2016). Pacienții cu PTE au fost identificați prin căutarea în baza de date a codurilor de diagnostic a tututor diagnosticelor de externare. Date demografice, clinice şi paraclinice au fost preluate din fişele medicale.

Rezultate. 221 pacienți (48.87\% bărbați, vârsta medie 61.76 ani (range 2194 ani)) au fost diagnosticați cu PTE în spitalul nostru (0.31\% din toate spitalizările). Dispneea a fost cel mai frecvent simptom raportat (78.9\%), urmată de durerea toracică pleuritică (23.9\%) şi durerea unilaterală de membru pelvin (15.8\%). La prezentare, $12.6 \%$ au avut PTE cu risc inalt. Până la $72.8 \%$ din pacienți au avut cel puțin un factor de risc trombotic, în timp ce cancerul (14\%) a fost cel mai frecvent dintre ei. Durata medie de spitalizare a fost $10.3 \pm 4.6$ zile. Heparina nefracționată (UFH) a fost anticoagulantul preferat pe durata spitalizării (73.7\%, $p<0.001)$. Antagoniştii de vitamină $K$ (AVK) au fost anticoagulantele preferate $(71.7 \%, p<0.001)$ după externare, în timp ce anticoagulantele orale 
non-antivitamină $K$ (NOAC) au fost recomandate la $26.3 \%$ din pacienți. Tromboliza a fost folosită în 18 (8.4\%) cazuri. Mortalitatea a fost $0.9 \%$.

Pacienții mai tineri au asociat mai frecvent trombofilii sau un eveniment tromboembolic anterior şi semne clinice de tromboză venoasă profundă la prezentare. Pacienții mai vârstnici au asociat mai frecvent istoric de spitalizare pentru insuficiență cardiacă sau fibrilație atrială în ultimile 3 luni sau istoric de cancer. Tabloul clinic la prezentare a fost mai sever în cazul pacienților mai vârstnici, cu scor PESI mai mare (103.6 \pm 33.4 vs. $55.5 \pm 17.9, p<0.001)$ şi durată mai mare de spitalizare (10.7 \pm 4.7 vs. 9.2 $\pm 3.9, p=0.03)$. Tipul de tratament anticoagulant nu a fost diferit în funcție de vârstă.

Concluzie. In spitalul nostru de urgență, PTE este o cauză relativ rară de internare; rata este însă comparabilă cu cea a altor spitale mari. Diapneea şi durerea toracică pleuritică a fost diada de prezentare clinică. UFH a fost anticoagulantul preferat pentru tratamentul în spital în timp ce AVK au fost opțiunea preferată pe termen lung şi profilaxia recurențelor; totuşi, unui număr în creştere de pacienți $i$-a fost prescris NOAC. La pacienții mai vârstnici, severitatea clinică la prezentare a fost mai mare, durata de spitalizare a fost mai crescută şi cancerul a fost mai frecvent asociat. Pacienții mai tineri au asociat mai frecvent un status hipercoagulant primar şi tromboembolism recurent. Mortalitatea a fost scăzută pe durata spitalizării, comparabilă cu cea observată în alte populații studiate.

Correspondence to: Elisabeta Bădilă, M.D, Ph.D

"Floreasca" Clinical Emergency Hospital Bucharest, Romania, 8, Floreasca Street, 014461

E-mail: elisabeta.badila@gmail.com

\section{REFERENCES}

1. STEIN PD, HULL RD, GHALI WA, PATEL KC, OLSON RE, MEYERS FA, et al. Tracking the uptake of evidence: two decades of hospital practice trends for diagnosing deep vein thrombosis and pulmonary embolism. Arch. Intern. Med. $2003 ; 163$ (10):1213-9.

2. JA H. The Epidemiology of Venous Thromboembolism in the Community: Implications for Prevention and Management. Journal of Thrombosis and Thrombolysis. 2006; 21 (1):23-9.

3. GOLDHABER SZ, VISANI L. The International Cooperative Pulmonary Embolism Registry. Chest. 1995; 108 (2):302-4.

4. BAUMANN KREUZIGER L, COTE L, VERHAMME P, GREENBERG S, CAPRINI J, MUNOZ FJ, et al. A RIETE registry analysis of recurrent thromboembolism and hemorrhage in patients with catheter-related thrombosis. Journal of vascular surgery. Venous and lymphatic disorders. 2015; 3 (3):243-50.e1.

5. AO. PETRIS GT-C, A. NECHITA, C. POP, M. VLADOIANU, L. PETRESCU, L. VIDA-SIMITI, D. TINT, D. CIMPOESU. Pulmonary embolism with and without acute heart failure: what makes the difference? Data from Romanian registry for pulmonary thromboembolism (RO-TEP). European Journal of HEart Failure Suppl. 2013:S267.

6. ZAMORANO JL, ACHENBACH S, BAUMGARTNER H, BAX JJ, BUENO H, DEAN V, et al. 2014 ESC Guidelines on the diagnosis and management of acute pulmonary embolism. The Task Force for the Diagnosis and Management of Acute Pulmonary Embolism of the European Society of Cardiology (ESC)Endorsed by the European Respiratory Society (ERS). Eur. Heart J. 2014; 35 (43):3033-73.

7. OGENG'O JA, OBIMBO MM, OLABU BO, GATONGA PM, ONG'ERA D. Pulmonary thromboembolism in an East African tertiary referral hospital. J. Thromb. Thrombolysis. 2011; 32 (3):386-91.

8. SCHISSLER AJ, ROZENSHTEIN A, SCHLUGER NW, EINSTEIN AJ. National trends in emergency room diagnosis of pulmonary embolism, 2001-2010: a cross-sectional study. Respir. Res. 2015; 16 (1):44.

9. SHEN J-H, CHEN H-L, CHEN J-R, XING J-L, GU P, ZHU B-F. Comparison of the Wells score with the revised Geneva score for assessing suspected pulmonary embolism: a systematic review and meta-analysis. J. Thromb. Thrombolysis. $2016 ; 41$ (3):482-92.

10. HEIT JA. Epidemiology of venous thromboembolism. Nature reviews. Cardiology. 2015; 12 (8):464-74.

11. GREEN RM, MEYER TJ, DUNN M, GLASSROTH J. Pulmonary embolism in younger adults. Chest. 1992; 101 (6):1507-11.

12. NIELSEN OW, HILDEN J, LARSEN CT, HANSEN JF. Cross sectional study estimating prevalence of heart failure and left ventricular systolic dysfunction in community patients at risk. Heart. 2001; 86 (2):172-8.

13. TORRE LA, SIEGEL RL, WARD EM, JEMAL A. Global Cancer Incidence and Mortality Rates and Trends - An Update. Cancer Epidemiol. Biomarkers Prev. 2016; 25 (1):16-27.

14. JANATA K, HOLZER M, DOMANOVITS H, MULLNER M, BANKIER A, KURTARAN A, et al. Mortality of patients with pulmonary embolism. Wiener klinische Wochenschrift. 2002; 114 (17-18):766-72. 
15. GOLDHABER SZ, VISANI L, DE ROSA M. Acute pulmonary embolism: clinical outcomes in the International Cooperative Pulmonary Embolism Registry (ICOPER). Lancet. 1999; 353 (9162):1386-9.

16. POLLACK CV, SCHREIBER D, GOLDHABER SZ, SLATTERY D, FANIKOS J, O'NEIL BJ, et al. Clinical characteristics, management, and outcomes of patients diagnosed with acute pulmonary embolism in the emergency department: initial report of EMPEROR (Multicenter Emergency Medicine Pulmonary Embolism in the Real World Registry). J. Am. Coll. Cardiol. 2011; 57 (6):700-6.

17. MARGOLIS JM, DEITELZWEIG S, KLINE J, TRAN O, SMITH DM, BOOKHART B, et al. Shorter Hospital Stays and Lower Costs for Rivaroxaban Compared With Warfarin for Venous Thrombosis Admissions. Journal of the American Heart Association: Cardiovascular and Cerebrovascular Disease. 2016; 5 (10):e003788.

18. ROBERTS KM, KNIGHT TB, PADILLA-TOLENTINO E, MURTHY M, PETERSON EJ. Length of Stay Comparison between Rivaroxaban and Warfarin in the Treatment of Pulmonary Embolism: Results from a Real-World Observational Cohort Study. Thrombosis. 2015; 2015:6.

19. INVESTIGATORS TEP. Oral Rivaroxaban for the Treatment of Symptomatic Pulmonary Embolism. N. Engl. J. Med. 2012; 366 (14):1287-97.

20. AGNELli G, BULLER HR, COHEN A, CURTO M, GALLUS AS, JOHNSON M, et al. Oral Apixaban for the Treatment of Acute Venous Thromboembolism. N. Engl. J. Med. 2013; 369 (9):799-808.

21. HANSLIK T, PRINSEAU J. The use of vitamin $K$ in patients on anticoagulant therapy: a practical guide. Am. J. Cardiovasc. Drugs. 2004; 4 (1):43-55.

Received June 20, 2017 